\title{
Terrorism and the integration of Muslim immigrants
}

Citation for published version (APA):

Elsayed, A., \& de Grip, A. (2018). Terrorism and the integration of Muslim immigrants. Journal of Population Economics, 31(1), 45-67. https://doi.org/10.1007/s00148-017-0646-z

Document status and date:

Published: 01/01/2018

DOI:

10.1007/s00148-017-0646-z

Document Version:

Publisher's PDF, also known as Version of record

\section{Document license:}

Taverne

\section{Please check the document version of this publication:}

- A submitted manuscript is the version of the article upon submission and before peer-review. There can be important differences between the submitted version and the official published version of record.

People interested in the research are advised to contact the author for the final version of the publication, or visit the DOI to the publisher's website.

- The final author version and the galley proof are versions of the publication after peer review.

- The final published version features the final layout of the paper including the volume, issue and page numbers.

Link to publication

\footnotetext{
General rights rights.

- You may freely distribute the URL identifying the publication in the public portal. please follow below link for the End User Agreement:

www.umlib.nl/taverne-license

Take down policy

If you believe that this document breaches copyright please contact us at:

repository@maastrichtuniversity.nl

providing details and we will investigate your claim.
}

Copyright and moral rights for the publications made accessible in the public portal are retained by the authors and/or other copyright owners and it is a condition of accessing publications that users recognise and abide by the legal requirements associated with these

- Users may download and print one copy of any publication from the public portal for the purpose of private study or research.

- You may not further distribute the material or use it for any profit-making activity or commercial gain

If the publication is distributed under the terms of Article $25 \mathrm{fa}$ of the Dutch Copyright Act, indicated by the "Taverne" license above, 


\title{
Terrorism and the integration of Muslim immigrants
}

\author{
Ahmed Elsayed ${ }^{1,2} \cdot$ Andries de Grip ${ }^{1,2}$
}

Received: 10 March 2016 / Accepted: 24 April 2017 / Published online: 6 May 2017

(C) Springer-Verlag Berlin Heidelberg 2017

\begin{abstract}
We study the effect that a series of Islamist terrorist attacks across Europe in 2004-2005 had on the integration of Muslim immigrants. Using unique panel data that oversamples immigrants in the Netherlands, we show that, shortly after the attacks, Muslim immigrants' attitudes toward integration worsened significantly compared to those of nonMuslim immigrants, with no evidence of a negative trend in the attitudes of Muslims prior to the attacks. While, in particular, low-educated Muslims became more geographically segregated and unemployed after the attacks, high-educated Muslims were affected most negatively in terms of their perceived integration. This decline in perceived integration is associated with a higher intention to permanently re-migrate to the country of origin.
\end{abstract}

Keywords Terrorism $\cdot$ Integration $\cdot$ Muslim immigrants

JEL Classification $\mathrm{F} 22 \cdot \mathrm{J} 15 \cdot \mathrm{R} 23 \cdot \mathrm{Z} 13$

\section{Introduction}

Islamist terrorist attacks on Western targets generally raised anti-Muslim feelings across the Western world. This paper investigates the extent to which the attitudes of Muslim immigrants toward integration in their host country are negatively affected by Islamist terrorism, and examines which groups of Muslims are affected most negatively by the terrorist attacks. We use a unique panel dataset from the Netherlands that oversamples immigrants and contains detailed information on their attitudes and feelings toward their host country. The dataset consists of two waves. The first wave was collected during 2002-2003, while the second wave was collected over 2006-2007. Between the two waves, Western Europe

Responsible editor: Klaus F. Zimmermann

Ahmed Elsayed

elsayed@iza.org

1 IZA Institute of Labor Economics, Schaumburg-Lippe-Strasse 5-9, 53113 Bonn, Germany

2 ROA, Maastricht University, Maastricht, The Netherlands 
witnessed the first violent wave of Islamist terrorism since September 11, 2001 (Bakker 2006). This wave began with the Madrid bombings on March 11, 2004, which were shown to have been directed by an Al Qaeda-affiliated group, killing 191 people and injuring $1841{ }^{1}$ The wave of attacks ended with the London bombings on July 7, 2005, which were committed by four Islamist suicide bombers, raised in the UK, leaving 52 people dead, including the four bombers, with over 700 injured. $^{2}$

The Netherlands was also heavily affected by this wave of radical Islamist terrorism when Theo van Gogh, a famous Dutch film director, TV interviewer, and writer, was murdered on November 2, 2004, by a young man of Moroccan origin who had recently converted to radical Islam. ${ }^{3}$ This attack received enormous media attention and triggered nationwide outrage against Muslims (Gautier et al. 2009). In the weeks following the murder, there were several attacks on mosques and other Islamic institutions in the Netherlands (Gautier et al. 2009). The survey Leefsituatie Allochtone Stedelingen collected data on city dwellers of various ethnic minorities in the Netherlands directly after the murder and asked their opinions on the murder's influence on the relationship between Muslims and non-Muslims. The great majority of the respondents, both native and foreign, reported that the murder had affected this relationship and $20 \%$ of the respondents of Moroccan origin and $13 \%$ of the respondents of Turkish origin reported that their lives, as well as those of their families, had been affected by the murder (Gijsberts 2005). The murder also took place amid unfavorable changes in the political domain for Muslims in the Netherlands. In 2004, member of Parliament Geert Wilders formed a new political party - the Partij Voor de Vrijheid, ("Party for Freedom") - with strong opinions against Muslim immigrants. In addition, a new immigration law was introduced in March 2006 with stricter requirements for immigrants entering the country for the purpose of family reunification/formation, including a civic integration exam in Dutch. The two political events can clearly be placed in the context of the changing cultural climate against foreigners, and particularly Muslim immigrants, in the Netherlands. ${ }^{4}$

Following the same individuals before and after the wave of terrorist events, we analyze changes in Muslim immigrants' integration in the Netherlands relative to those for non-Muslim immigrants using subjective measures of integration attitudes. ${ }^{5}$ We find

\footnotetext{
${ }^{1}$ See http://news.bbc.co.uk/2/shared/spl/hi/guides/457000/457031/html/.

2 Detailed coverage of the 2005 London attacks can be found at the BBC website at http://news.bbc.co.uk/2 /hi/in_depth/uk/2005/london_explosions/default.stm.

${ }^{3}$ With the exception of some terrorist conspiracies and threats, there were no high-profile terrorist attacks in Europe from September 11, 2001, to March 10, 2004 (Nesser 2008). According to the Global Terrorism Database (2012), the three attacks listed above were the most significant Islamist terrorism attacks in Europe. For extensive details on fundamentalist Islamic terrorism in Europe over this period, see Bakker (2006, pp. 3-4).

${ }^{4}$ This was also accompanied by a wave of increased xenophobic attitudes among locals. Data from the World Values Survey show that the share of the Dutch who would not like to have immigrants/foreign workers as neighbors jumped from about $10 \%$ in 2005 to around $20 \%$ in 2012 . See: http://www.worldvaluessurvey. org/wvs.jsp.

5 As the social integration process of foreign minorities takes generations, assessing changes in immigrants' integration over a short period of time would prove difficult using traditional measures of integration such as language use, importance of religion, attitudes toward intra-marriage, etcetera. Integration attitudes, however, represent the basis of the integration process and could therefore capture the integration potential. Georgiadis and Manning (2013) show that immigrants who feel tolerated by natives are more likely to identify with the host country.
} 
that Muslim immigrants' attitudes toward integration into Dutch society became much more negative than those of non-Muslim immigrants following the terrorist attacks. This pattern is robust to the inclusion of a large set of controls, such as sociodemographics, employment status, and length of stay in the Netherlands. The pattern is also robust after controlling for selection bias. Since our data consist of only two waves, it is difficult to attribute the decline in the integration pattern of Muslims solely to the sociopolitical atmosphere associated with terrorism. Other factors could have affected the speed at which different immigrant groups integrate. To check this possibility, we exploit the relatively long timeframe during which the data were collected in the first wave and use the timing of interviews to estimate whether a declining trend in the integration of Muslims relative to non-Muslims was already observed prior to the terrorist attacks. This analysis shows no evidence of a decline in Muslim immigrants' integration before the terrorist attacks, suggesting that it was the wave of terrorism and its sociopolitical consequences that caused the change in the integration pattern of Muslims in the Netherlands.

We also estimate the effect of the attacks on geographic segregation and labor market outcomes. We find that the geographic segregation of Muslim immigrants increased after the attacks. This finding is in line with those of Gautier et al. (2009), where housing prices in Amsterdam declined in neighborhoods with a large share of Muslim immigrants after the murder of Theo van Gogh. ${ }^{6}$ While unemployment and working hours were not affected by the attacks, on average, our analyses on the heterogeneous effects show that low-educated Muslims were affected negatively in terms of labor market outcomes and became more geographically segregated after the attacks, while highly educated Muslims were affected the most negatively with respect to their integration attitudes.

The remainder of the paper is organized as follows. Section 2 discusses the literature. Section 3 explains the empirical strategy. Section 4 describes the data and variables used in the paper. Section 5 reports the results of the data analyses and describes the robustness checks. Finally, Section 6 summarizes the findings and concludes.

\section{Related literature}

Becker's theory of taste-based discrimination (Becker 1957) provides a plausible framework for studying the impact of fundamentalist Islamic terrorism on Muslim immigrants. As a consequence of the Islamist terrorist attacks, locals could develop a (greater) distaste for Muslims, which induce them to reduce their interaction with Muslims, ignore them, or commit hate crimes against them in the extreme case (Gould and Klor 2015; Hanes and Machin 2014). This distaste increases the level of perceived discrimination by Muslim immigrants and decreases their integration in the host country. ${ }^{7}$

Based on this framework, an emerging body of economic literature investigates the impact of Islamist terrorism on different outcomes of Muslim immigrants (e.g., Cornelissen

\footnotetext{
${ }^{6}$ Unlike Gautier et al. (2009), who studied the effect of terrorism on Muslim immigrants at the neighborhood level, we show changes in the geographic segregation of Muslims using data at the individual level. One advantage of our approach is the ability to study the heterogeneous effects of the impact of terrorism on Muslim immigrants.

${ }^{7}$ Some studies exploit exogenous shifts in natives' ethnic preferences to study taste-based discrimination (e.g., Michaels and Zhi 2010; Moser 2012) and in-group preference (e.g., Shayo and Zussman 2011).
} 
and Jirjahn 2012; Gautier et al. 2009; Goel 2010; Hanes and Machin 2014; Johnston and Lordan 2012; Kaushal et al. 2007; Shannon 2012). ${ }^{8}$ The literature shows increasing discrimination against Muslims as a result of terrorism (Goel 2010; Hanes and Machin 2014), as well as negative impacts of this discrimination on Muslim immigrants' geographic segregation (Gautier et al. 2009) and health (Johnston and Lordan 2012). However, the effect of terrorism on Muslim immigrants' labor market outcomes is not clear-cut in the literature. While some studies find that terrorism has had a negative effect on the labor market position of Muslims (e.g., Dávila and Mora 2005; Kaushal et al. 2007), ${ }^{9}$ other studies find little or no effect (e.g., Åslund and Rooth 2005; Braakmann 2010; Shannon 2012). Others find that only particular groups of Muslims were affected, such as the young (Rabby and Rodgers 2010, 2011) and the low skilled (Cornelissen and Jirjahn 2012).

The failure of labor market outcomes to measure discrimination could be explained by the highly regulated nature of the European labor markets (Åslund and Rooth 2005; Cornelissen and Jirjahn 2012), as well as by immigrants' participation in networks of the same ethnic minority. Active participation in these networks is usually associated with positive labor outcomes (Casey and Dustmann 2010). This suggests that the identification of immigrants with their home country, as opposed to the host country, could be positively associated with labor market outcomes. These countervailing mechanisms could explain why, overall, evidence of the impact of the terrorist attacks on the labor market position of Muslims is mixed. However, while the impact of terrorism on labor market discrimination remains inconclusive, Muslims could also be affected in terms of geographic segregation (Gautier et al. 2009). The dislike of Muslims due to the terrorist attacks could make natives move out of municipalities with high concentrations of Muslims, while Muslims could be more eager to move to such areas to obtain social support from being in a community of the same ethnic or religious background. Both scenarios will lead to higher levels of segregation among Muslim immigrants.

Moreover, the terrorist attacks could have long-term effects for Muslim migrants. Gould and Klor (2015) exploit variations across US states in the number of hate crimes against Muslims in the wake of September 11 and show that September 11 had long-term effects on intermarriage, fertility, female labor force participation, and English proficiency among Muslim immigrants. The authors argue that a major goal of terrorist attacks is to induce a backlash against Muslims to radicalize moderate supporters who live in the same country as the perpetrators. ${ }^{10}$ However, despite the growing economic literature on the integration of Muslim immigrants in western societies (e.g., Adida et al. 2014; Arai et al. 2011; Battu and Zenou 2010; Bisin et al. 2008; Georgiadis and Manning 2011, 2013; Manning and Roy 2010; Mitrut and Wolff 2014), no studies have used a panel structure to estimate changes in the integration attitudes of Muslim immigrants over time while

\footnotetext{
${ }^{8}$ The impact that large-scale fundamentalist Islamic terrorist attacks have on discrimination is not limited to the country in which the attacks take place. For example, Schüller (2016) shows that September 11 resulted in a significant increase in negative attitudes toward immigration and decreased concerns over xenophobic hostility among the native German population.

${ }^{9}$ In a similar vein, Miaari et al. (2012) showed that the second Intifada in 2000 increased job separation rate for Arab workers in Israel, relative to Jew workers.

${ }^{10}$ In addition to this strategic objective for terrorism, the literature discusses several other political objectives such as changing standpoints of governments (Kydd and Walter 2006), or switching political attitudes of locals leftwards (Gould and Klor 2010), in addition to economic objectives such as causing large movements of capital across countries (Abadie and Gardeazabal 2008).
} 
accounting for unobserved heterogeneity. Therefore, there is no evidence which groups of individuals are most affected in terms of their perceived integration. ${ }^{11}$

While the impact of terrorist attacks on objective outcomes is expected to be more pronounced for low-educated immigrants (Cornelissen and Jirjahn 2012), discrimination is more likely to be perceived by highly educated immigrants because of their high expectations of integration in the host country. Banerjee (2008) indeed finds that immigrants' perceived discrimination is not related to objective measures of income inequity. The author shows that, in workplace settings, long-term immigrants and highly educated immigrants perceive discrimination more strongly than new immigrants and loweducated immigrants, respectively, because of their expectations of equitable treatment.

\section{Empirical strategy}

To identify the effect of the terrorist attacks in Western Europe, and their sociopolitical aftermath on the integration of Muslim immigrants, we estimate the equation

$$
Y_{i t}=\alpha+\beta_{1} M_{i t}+\beta_{2} P A_{t}+\beta_{3}\left[M_{i t} \times P A_{t}\right]+\beta_{4} X_{i t}+u_{i}+\varepsilon_{i t}
$$

where $Y_{i t}$ is the integration level of immigrant $i$ at time $t, M$ is a dummy variable that takes the value one if the respondent is Muslim and zero otherwise, $P A$ is a dummy variable that takes the value one if the observation is from the second wave of the study (after the terrorist attacks) and zero otherwise, the parameter $\beta_{3}$ for the interaction between $M$ and $P A$ is our measure of change in Muslims' integration compared to that of non-Muslims, $X_{i t}$ is a set of controls, $u_{i}$ is an individual fixed effect (FE) that we assume to be uncorrelated with the timings of the terrorist attacks, and $\varepsilon_{i t}$ is a timevarying error term.

\section{Data and descriptive statistics}

To study the impact of the terrorist attacks on the perceived integration of Muslims, we use panel data from the Netherlands Kinship Panel Study SPVA (Social Position and Facilities Use of Ethnic Minorities) survey, which oversamples immigrants from the four largest immigrant groups in the Netherlands: Turks, Moroccans, Surinamese, and Dutch Antilleans. The data were collected from 13 Dutch cities, in which at least half of the immigrant population lives (Dykstra et al. 2005, 2012). The panel dataset consists of two waves. The first wave was collected between April 2002 and October 2003, while the second was collected between May 2006 and June 2007. ${ }^{12}$ The dataset contains individual information about religion, age, level of education, ethnic group,

\footnotetext{
$\overline{11}$ Goel (2010) estimates changes in perceptions of discrimination among Muslim-looking immigrants in Australia using a cross section of recently arrived immigrants, making it difficult to account for unobserved immigrant heterogeneity. In addition, the measures used in her study are limited to binary perceptions of intolerance and discrimination. Our study goes one step further, beyond perceptions of fair/unfair treatment, and assesses changes in immigrants' feeling at ease with natives and attitudes toward living in the host country. 12 The long period over which the data were collected is due to the difficulty in reaching the target groups (Dykstra et al. 2005, 2012).
} 
employment status, marital status, year of immigration, and so forth. Furthermore, we include information about the share of the individuals' own ethnic groups in the municipalities in which they live, drawn from Statistics Netherlands. ${ }^{13}$

The dataset also includes information about immigrants' attitudes toward integration. The respondents were asked eight questions on the extent to which they agreed with each of the following statements: (1) "In the Netherlands foreigners have excellent opportunities," (2) "The Dutch are hostile to foreigners," (3) "In the Netherlands your rights as a foreigner are respected," (4) "The Dutch are hospitable to foreigners," (5) "In the Netherlands people are indifferent to foreigners," (6) "Foreigners are treated fairly in the Netherlands," (7) "Foreigners face many restrictions in the Netherlands," and (8) "The Dutch are open to foreign cultures." The answers were given on a five-point scale, ranging from one ("strongly disagree") to five ("strongly agree"). Respondents were also asked about their appreciation of living in the Netherlands-(9) "How do you like living in the Netherlands?" (with answers ranging from one, "very fine," to five, "very annoying") - and their social experience with locals - (10) "Do you feel at ease in the company of Dutch people?" (with answers on a four-point scale, with one for "no, not at all," two for "no, not really," three for "yes, a little," and four for "yes, very much so"). ${ }^{14}$

We use a balanced sample of 432 observations (216 individuals in each wave) for whom we have full information on all integration attitudes, demographics, and religion. Of this set, 280 observations (140 individuals in each wave) are for Muslim immigrants and 152 observations (76 individuals in each wave) are for non-Muslim immigrants. Table 6 in the Appendix provides an overview of the integration attitudes and variables used in the study. The table shows that non-Muslim immigrants scored significantly higher than Muslims in most of the integration items. In our sample, 56\% of non-Muslims and $41 \%$ of Muslims were females. Muslims are more often low educated (i.e., more likely to have lower secondary education or below). ${ }^{15}$ While the majority of Muslims belong to the Turkish and Moroccan ethnic minorities, the majority of non-Muslims belong to the Surinamese and Dutch Antillean ethnic minorities. Geographic concentration in municipalities (estimated by the share of migrants with the same ethnic background in a municipality) was higher for Muslim than for non-Muslim immigrants. Non-Muslims were more likely to be employed (65\%) than Muslims (53\%). In addition, a greater percentage of Muslims in our sample were married and had children.

Figure 1 shows the changes in integration attitudes for both Muslim and non-Muslim immigrants between the two waves of the study (the integration attitudes are standardized for ease of comparison). The figure shows that, between the two waves, integration attitudes became more negative for both groups. However, the change is much more pronounced among Muslims than among non-Muslims. Table 7 in the Appendix summarizes the changes and shows the difference-in-difference estimates of the integration items. The difference-in-difference coefficients show that the decline was more significant for Muslims than for non-Muslims over different measures of integration attitudes.

\footnotetext{
${ }^{13}$ See the Statistics Netherlands website: http://statline.cbs.nl/StatWeb/.

${ }^{14}$ The first eight items are used in the sociological literature as a measure of perceived acceptance by the host country (Huijnk et al. 2012). The scale for items (2), (5), (7), and (9) is reversed so that the higher the value, the better the outcome in terms of integration.

${ }^{15}$ We here follow the definition used in the literature (e.g., Steedman and McIntosh 2001) which defines the low educated as those who have lower secondary education or below, and the higher educated as those with upper secondary education or higher.
} 


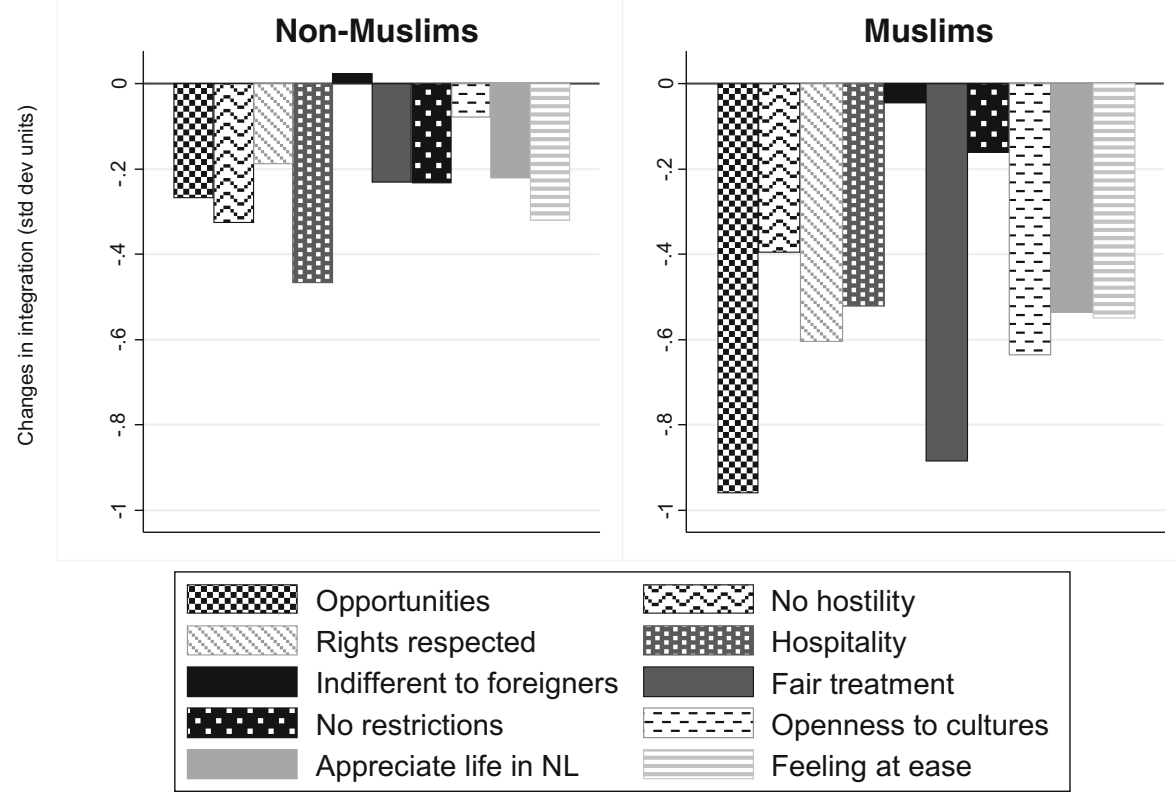

Fig. 1 Changes in the integration attitudes

We use an integration index constructed by grouping the 10 individual items. This has the advantage of reducing the likelihood of type I errors (where the result for any single item is due to chance) and type II errors (the risk of low statistical power) (Clingingsmith et al. 2009). Following Kling et al. (2007), we estimate an index of the equally weighted averages of the $z$-scores of the 10 items. The $z$-scores are calculated by subtracting the control group's (non-Muslims) mean and dividing by the control group's standard deviation. Therefore, for the non-Muslims in our sample, each item in the index has mean zero and standard deviation one. ${ }^{16}$ Table 7 shows the decline in our integration index (hereafter, perceived integration) is much more pronounced for Muslims.

\section{Data analyses}

\subsection{Baseline model}

To investigate the impact of Islamist terrorism on the integration of Muslims, we estimate Eq. (1) using a FE and a generalized least squares model with

\footnotetext{
${ }^{16}$ An alternative approach is to compute the average effect size across items within the integration index, using seemingly unrelated regression for the 10 items to estimate the covariance of the effects and then calculating the mean effect size for the 10 items in a second step (Clingingsmith et al. 2009; Kling and Liebman 2004). Since we use a consistent number of observations across the 10 items of integration and there are no regression adjustments, the two approaches give identical results (Kling et al. 2007). Without a consistent number of observations, the results would remain very similar. The advantage of the average $z$ score index used in this paper is that it is much simpler to work with, especially when using panel data (Kling et al. 2007).
} 
random effects (RE) clustered on personal identification. ${ }^{17}$ Table 1 shows the coefficients of the two models without and with a large set of control variables (see table footnotes). The table shows that the perceived integration of Muslim immigrants in the Netherlands decreased significantly after the attacks relative to the perceived integration of non-Muslim immigrants. This result can be seen in the interaction coefficients between Muslim and Post-attacks, which are negative and statistically significant. ${ }^{18}$ To investigate the possibility that differences in control variables between Muslim and non-Muslim immigrants could be driving the results, Table 8 in the Appendix replicates the FE analysis after controlling for the interaction between being Muslim and all relevant control variables (column 1). And to account for the possibility that changes in the control variables over time are driving the change in perceived integration, we control for the interaction between Post-attacks and all relevant control variables (column 2). The table shows that both model specifications yield similar results as the baseline model in Table 1.

We also estimated the model using the individual items of the integration index. Table 9 in the Appendix shows the interaction coefficients for each of the 10 items separately. Among the different items, perceptions of excellent opportunities, fair treatment, openness to foreign cultures, and appreciation of living in the Netherlands are affected most negatively by the terrorist attacks. To account for the possibility that the decrease in integration is affected by extremely positive pre-attack levels of integration attitudes, Table 10 in the Appendix re-estimates the model after excluding the most positive pre-attack levels of integration (top 10\%). The estimation results remain unchanged.

\subsection{Possible trend prior to the terrorist attacks}

Some studies show that September 11 was associated with labor market discrimination against certain minority groups and changed attitudes toward immigrants not only in the USA but also in other Western countries (e.g., Cornelissen and Jirjahn 2012; Goel 2010; Schüller 2016). Since the period we analyze starts after the September 11 attacks, the effect we find could be due to a negative trend in perceived integration of Muslim immigrants that had already set in after September 11, 2001. However, the analysis

\footnotetext{
${ }^{17}$ The Breusch Pagan Lagrangian multiplier test rejects the null hypothesis and therefore suggests the use of random effects model over OLS.

${ }^{18}$ We acknowledge the potential for selection bias due to panel attrition in the dataset; of the 469 respondents for whom we have information on integration and background characteristics in the first wave, only 216 were also present in the second wave. To deal with the selection bias, we replicated the analysis after controlling for Mills ratio using a selection variable that equals one if the individual is observed in the two waves of the study as our dependent variable in the selection equation. As an exclusion restriction, we used a dummy variable that takes the value one if the number of missing items in the respondents' answers to all the questions in the first wave is above the median and zero otherwise (Huijnk et al. 2012). This variable is used to satisfy the exclusion restriction, which is possible since the likelihood that a respondent will be absent from the second wave should be correlated with the number of questions the respondent did not answer in the first wave. (i.e., immigrants who answered fewer questions in the first wave should be more likely to drop out in the second wave). However, the number of missing answers should not be correlated with the timing of the terrorist attacks. The results (that can be obtained from the corresponding author) are similar to those shown in Table 1.
} 
Table 1 Change in the integration of Muslim and non-Muslim immigrants after the terrorist attacks, balanced panel data

\begin{tabular}{|c|c|c|c|c|}
\hline \multirow[b]{2}{*}{ Variables } & \multicolumn{2}{|l|}{$\mathrm{FE}$} & \multicolumn{2}{|l|}{$\mathrm{RE}$} \\
\hline & (1) & (2) & (3) & (4) \\
\hline \multirow[t]{2}{*}{ Muslim } & - & - & -0.116 & 0.038 \\
\hline & & & $(0.076)$ & $(0.198)$ \\
\hline \multirow[t]{2}{*}{ Post-attacks } & $-0.223^{\mathrm{c}}$ & -0.347 & $-0.223^{\mathrm{c}}$ & $-0.236^{\mathrm{c}}$ \\
\hline & $(0.053)$ & $(0.288)$ & $(0.053)$ & $(0.060)$ \\
\hline \multirow[t]{2}{*}{ Muslim $\times$ Post-attacks } & $-0.287^{\mathrm{c}}$ & $-0.323^{\mathrm{c}}$ & $-0.287^{\mathrm{c}}$ & $-0.313^{\mathrm{c}}$ \\
\hline & $(0.100)$ & $(0.107)$ & $(0.100)$ & (0.109) \\
\hline \multirow[t]{2}{*}{ Constant } & $0.071^{\mathrm{c}}$ & -0.256 & $0.111^{\mathrm{b}}$ & -0.135 \\
\hline & $(0.023)$ & $(1.311)$ & $(0.048)$ & $(0.278)$ \\
\hline Controls & No & Yes & No & Yes \\
\hline Observations & 432 & 432 & 432 & 432 \\
\hline Number of individuals & 216 & 216 & 216 & 216 \\
\hline
\end{tabular}

Perceived integration is measured by an index of the equally weighted averages of the $z$-scores (based on the mean and standard deviation of the non-Muslim group) of the 10 integration items. The variable Muslim is a dummy variable for being Muslim and Post-attacks takes the value one if the observation is from the second wave (after the terrorist attacks) and zero otherwise. Controls include employment status, education, marital status, number of children, length of stay in the Netherlands (squared), and regional dummies. In the RE model, controls also include time-invariant variables on gender, and ethnic group. Respondents' age is removed because of potential collinearity with length of stay in the Netherlands. However, adding the variable yields similar results. Robust standard errors are in parentheses

${ }^{\mathrm{b}}$ Significant at $5 \%$

${ }^{\mathrm{c}}$ Significant at $1 \%$

above (Table 1) does not show strong evidence of differences in integration between Muslims and non-Muslims before the wave of terrorist attacks in which we are interested. Furthermore, even if Muslims were less integrated, this would make our point stronger, since it underestimates our coefficients for the decrease in Muslims' integration.

However, if a pattern of change in Muslim immigrants' integration began before the wave of terrorism of interest (i.e., before March 2004), this would imply that the change in Muslim immigrants' attitudes was not a result of the terrorist attacks but could, instead, be due to endogenous factors that affect the speed of integration differently for Muslim and non-Muslim immigrants. To account for this possibility, we exploit the timing of interviews during the first wave of the dataset to analyze whether Muslims interviewed late in the first wave reported lower integration attitudes than those interviewed earlier. If such a pattern is already observed before the terrorist attacks, it would be difficult to attribute the decline in the integration of Muslim immigrants to the terrorist attacks. Since the first wave of the data was collected over quite a long timeframe, a trend could be identified. 
Figure 2 shows the unconditional trends in the integration of Muslim and non-Muslim immigrants in the two waves of the study. The graph shows that, during the first wave of the survey, the integration of Muslims was increasing relative to that of non-Muslims. This result suggests no pre-trend in the relative decline in the integration of Muslims. The figure also clearly shows a drop in the integration for the two groups of immigrants in the second wave, compared to the first wave, with a far more pronounced drop for Muslim immigrants. However, the integration seems to slightly recover during the second wave for the two groups.

Table 11 in the Appendix shows the coefficients for the regression of integration on the time of the interviews, measured in quarters, during the first wave (column 1) and second wave (column 2) of the study. The table shows that our finding that there was no negative pre-trend in the integration of Muslims compared to non-Muslims is robust to controlling for all relevant information.

\subsection{Heterogeneous effects}

In this section, we examine the extent of heterogeneity in the decline of integration of Muslim immigrants with respect to the pre-attacks covariates of
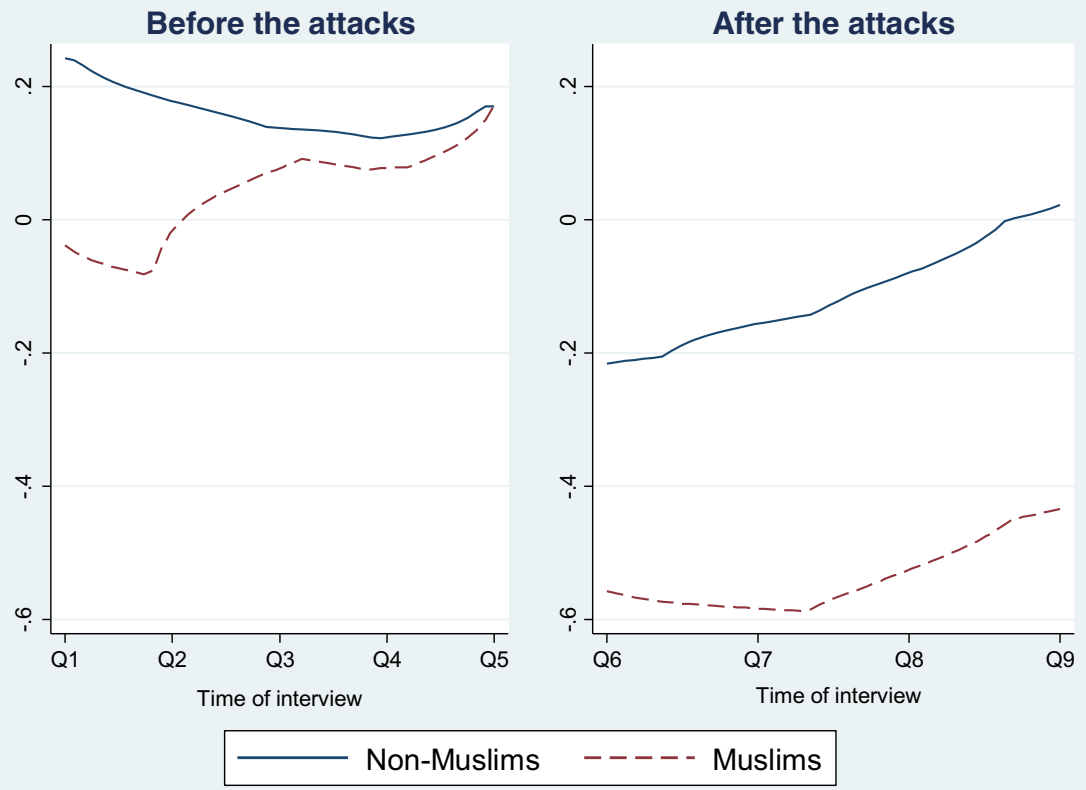

Fig. 2 Unconditional trends in the integration of immigrants before and after the terrorist attacks. The graph is based on a panel of 202 observations before the attacks and 212 observations after the attacks. The time of interview is in quarters: $Q 1=$ April to June 2002, $Q 2=$ July to September 2002, $Q 3=$ October to December 2002, $Q 4$ = January to March 2003, Q5 = April to July 2003, Q6 = June to August 2006, $Q 7=$ September to November 2006, $Q 8=$ December 2006 to February 2007, $Q 9=$ March 2007 to May 2007 
Table 2 Change in the integration of Muslim and non-Muslim immigrants after the terrorist attacks, FE estimates with heterogeneity by gender, age, education, geographic concentration, labor market status, and religiosity

Perceived integration

Variables

(1)

(2)

\begin{tabular}{|c|c|c|}
\hline (A) Gender & Men & Women \\
\hline \multirow[t]{2}{*}{ Muslim $\times$ Post-attacks } & $-0.310^{\mathrm{b}}$ & $-0.301^{\mathrm{a}}$ \\
\hline & $(0.149)$ & $(0.167)$ \\
\hline Observations & 214 & 218 \\
\hline Number of Individuals & 107 & 109 \\
\hline (B) Age & $\leq 40$ & $>40$ \\
\hline \multirow[t]{2}{*}{ Muslim $\times$ Post-attacks } & $-0.432^{\mathrm{c}}$ & -0.160 \\
\hline & $(0.146)$ & $(0.177)$ \\
\hline Observations & 200 & 232 \\
\hline Number of Individuals & 100 & 116 \\
\hline (C) Education & High & Low \\
\hline \multirow[t]{2}{*}{ Muslim $\times$ Post-attacks } & $-0.655^{\mathrm{c}}$ & -0.216 \\
\hline & $(0.150)$ & $(0.143)$ \\
\hline Observations & 202 & 230 \\
\hline Number of Individuals & 101 & 115 \\
\hline (D) Labor market status & Employed & Unemployed \\
\hline \multirow[t]{2}{*}{ Muslim $\times$ Post-attacks } & $-0.410^{\mathrm{c}}$ & -0.186 \\
\hline & $(0.132)$ & $(0.181)$ \\
\hline Observations & 256 & 176 \\
\hline Number of Individuals & 128 & 88 \\
\hline (E) Geographic concentration & High (above median) & Low (below median) \\
\hline \multirow[t]{2}{*}{ Muslim $\times$ Post-attacks } & $-0.309^{\mathrm{b}}$ & $-0.392^{\mathrm{c}}$ \\
\hline & $(0.150)$ & $(0.142)$ \\
\hline Observations & 216 & 216 \\
\hline Number of individuals & 108 & 108 \\
\hline (F) Religiosity & Less religious & More religious \\
\hline \multirow[t]{2}{*}{ Post-attacks } & $-0.633^{\mathrm{c}}$ & $-0.483^{b}$ \\
\hline & $(0.133)$ & $(0.176)$ \\
\hline Observations & 92 & 60 \\
\hline Number of individuals & 46 & 30 \\
\hline
\end{tabular}

Controls, as in Table 1. The low-education group is the group with elementary education, lower vocational education, or lower secondary education. The high-education group is the group with intermediate vocational education, intermediate and upper general secondary education, higher vocational education, or university education. The employed variable takes the value one if the individual was employed in the first wave and zero otherwise and religiosity is a dummy variable that takes the value one if the Muslim respondent went to the mosque frequently and zero if the respondent hardly went to the mosque. We limit the analysis of religiosity to Muslims. Therefore, the coefficient for Post-attacks will capture the changes for less religious Muslims (column 1) and more religious Muslims (column 2). For all estimations, we use the pre-attack level of the variable as a basis for the division. Robust standard errors are in parentheses

\footnotetext{
${ }^{a}$ Significant at $10 \%$

${ }^{\mathrm{b}}$ Significant at $5 \%$

${ }^{\mathrm{c}}$ Significant at $1 \%$
} 
gender, age, level of education, labor market status, geographic segregation, and degree of religiosity. Table 2 shows the results of the $\mathrm{FE}$ estimations from Table 1 for split samples by gender (panel A), age (panel B), education level: intermediate secondary education or above vs. lower secondary education or below (panel C), labor market status: employed vs. unemployed (panel D), geographic concentration: above vs. below median share of migrants with same ethnic background (panel E), and degree of religiosity: if the Muslim respondent goes to the mosque frequently vs. hardly (panel F). The decrease in the integration of Muslims seems to be more pronounced for male, young, highly educated, employed, and less religious Muslims. Muslims living in areas with lower levels of geographic concentration are also more likely to feel less integrated after the terrorist attacks compared to Muslims living in more segregated areas, although this difference is not statistically significant. These findings show that Muslim immigrants with high potential for integration were affected the most negatively. This result could be explained in light of their high expectations of integration in the host country. While this group of Muslims is more likely to have expected to be dealt with similarly to natives (Banerjee 2008), deviations from this expectation due to perceived discrimination could have led them to feel unintegrated within their host country. Moreover, those who are employed interact more often with natives than the non-

Table 3 Change in geographic concentration, unemployment, and working hours after the terrorist attack, FE

\begin{tabular}{llll}
\hline & Geographic concentration & Unemployment & Log working hours \\
& $(1)$ & $(2)$ & $(3)$ \\
\hline Muslim & - & - & - \\
Post-attacks & $0.763^{\mathrm{b}}$ & -0.127 & -0.155 \\
& $(0.329)$ & $(0.169)$ & $(0.105)$ \\
Muslim $\times$ Post-attacks & $0.199^{\mathrm{c}}$ & 0.064 & -0.026 \\
& $(0.079)$ & $(0.050)$ & $(0.038)$ \\
Constant & $0.061^{\mathrm{c}}$ & -0.343 & $2.934^{\mathrm{c}}$ \\
& $(0.014)$ & $(0.735)$ & $(0.493)$ \\
Controls & Yes & Yes & Yes \\
Observations & 432 & 432 & 220 \\
Number of individuals & 216 & 216 & 110 \\
\hline
\end{tabular}

Unemployment is a dummy variable that takes the value one if the respondent is unemployed and zero otherwise. Log working hours refer to log of actual working hours. Geographic concentration is the share of people with the same ethnic background in the municipality where the respondent lives. Controls include education, marital status, number of children, length of stay in the Netherlands (squared), and regional dummies. The working hour estimates are conditional on being employed. Replicating the analysis using a sample that included observations with zero working hours gives similar results. Robust standard errors are in parentheses

${ }^{\mathrm{b}}$ Significant at $5 \%$

${ }^{\mathrm{c}}$ Significant at $1 \%$ 
Table 4 Change in geographic concentration, unemployment, and working hours after the terrorist attacks, FE estimates with heterogeneity by gender, age, and education

\begin{tabular}{|c|c|c|c|c|c|c|}
\hline \multirow[t]{3}{*}{ Variables } & \multicolumn{2}{|l|}{ Gender } & \multicolumn{2}{|l|}{ Age } & \multicolumn{2}{|l|}{ Education } \\
\hline & Male & Female & $\leq 40$ & $>40$ & Low educ. & High educ. \\
\hline & (1) & (2) & (3) & (4) & $(5)$ & (6) \\
\hline \multicolumn{7}{|l|}{ Geographic concentration } \\
\hline \multirow[t]{2}{*}{ Muslim $\times$ Post-attacks } & $0.324^{\mathrm{a}}$ & $0.320^{\mathrm{c}}$ & 0.154 & $0.201^{\mathrm{a}}$ & $0.327^{\mathrm{c}}$ & 0.102 \\
\hline & $(0.180)$ & $(0.070)$ & $(0.147)$ & $(0.117)$ & $(0.076)$ & $(0.140)$ \\
\hline Observations & 214 & 218 & 200 & 232 & 230 & 202 \\
\hline Number of individuals & 107 & 109 & 100 & 116 & 115 & 101 \\
\hline \multicolumn{7}{|l|}{ Unemployment } \\
\hline \multirow[t]{2}{*}{ Muslim $\times$ Post-attacks } & $0.130^{\mathrm{a}}$ & -0.003 & 0.032 & 0.071 & $0.163^{\mathrm{a}}$ & 0.004 \\
\hline & $(0.069)$ & $(0.068)$ & $(0.073)$ & $(0.074)$ & $(0.083)$ & $(0.049)$ \\
\hline Observations & 214 & 218 & 200 & 232 & 230 & 202 \\
\hline Number of individuals & 107 & 109 & 100 & 116 & 115 & 101 \\
\hline \multicolumn{7}{|l|}{ Working hours } \\
\hline \multirow[t]{2}{*}{ Muslim $\times$ Post-attacks } & -0.025 & -0.035 & -0.044 & 0.027 & -0.023 & -0.031 \\
\hline & $(0.044)$ & $(0.088)$ & $(0.058)$ & $(0.045)$ & $(0.049)$ & $(0.051)$ \\
\hline Observations & 136 & 84 & 120 & 100 & 98 & 122 \\
\hline Number of individuals & 68 & 42 & 60 & 50 & 49 & 61 \\
\hline
\end{tabular}

See Table 3. The controls are as in Table 3. Robust standard errors are in parentheses

a Significant at $10 \%$

${ }^{\mathrm{c}}$ Significant at $1 \%$

employed and are therefore more likely to encounter harassments and perceive discrimination.

\subsection{Labor market outcomes and geographic segregation}

In this section, we estimate the effect of the terrorist attacks on Muslim immigrants' geographic concentration, unemployment, and working hours. ${ }^{19}$ Table 3 shows that the geographic segregation of Muslim immigrants relative to non-Muslim immigrants significantly increased over time. The share of people with the same ethnic background increased by about 0.2 percentage points for Muslims compared to non-Muslims after the attacks. The table further shows that unemployment and working hours of Muslims were not negatively affected by the terrorist attacks. However, the heterogeneous treatment effects for geographic concentration and labor market outcomes (Table 4) show that the effect of the terrorist attacks seems to be more pronounced for

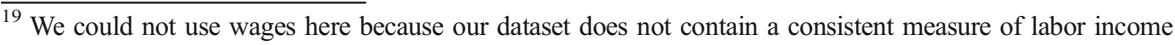
across the two panel waves.
} 
Table 5 Relation between the change in perceived integration and the intention to return to one's native country, marginal effects based on probit model

\begin{tabular}{|c|c|}
\hline Variables & Intention to return to native country \\
\hline Change in perceived integration & $\begin{array}{l}-0.113^{\mathrm{b}} \\
(0.048)\end{array}$ \\
\hline Pre-attacks perceived integration & $\begin{array}{l}-0.108^{\mathrm{a}} \\
(0.059)\end{array}$ \\
\hline Muslim & $\begin{array}{l}-0.141 \\
(0.140)\end{array}$ \\
\hline \multicolumn{2}{|l|}{ Ref: Employed } \\
\hline Unemployed & $\begin{array}{l}-0.135 \\
(0.091)\end{array}$ \\
\hline Housewife & $\begin{array}{l}-0.028 \\
(0.107)\end{array}$ \\
\hline Disabled & $\begin{array}{l}-0.077 \\
(0.091)\end{array}$ \\
\hline Student & $\begin{array}{l}0.073 \\
(0.247)\end{array}$ \\
\hline Retired & $\begin{array}{l}0.072 \\
(0.135)\end{array}$ \\
\hline Female & $\begin{array}{l}-0.023 \\
(0.065)\end{array}$ \\
\hline \multicolumn{2}{|l|}{ Ref: Unmarried } \\
\hline Married & $\begin{array}{l}-0.018 \\
(0.089)\end{array}$ \\
\hline Divorced & $\begin{array}{l}-0.092 \\
(0.085)\end{array}$ \\
\hline Widowed & $\begin{array}{l}-0.050 \\
(0.163)\end{array}$ \\
\hline Number of children & $\begin{array}{r}-0.004 \\
(0.019)\end{array}$ \\
\hline Length of stay in NL & $\begin{array}{l}0.020 \\
(0.014)\end{array}$ \\
\hline Length of stay in NL (squared) & $\begin{array}{l}-0.036 \\
(0.029)\end{array}$ \\
\hline Highly educated & $\begin{array}{l}-0.051 \\
(0.062)\end{array}$ \\
\hline Geographic concentration & $\begin{array}{l}0.017 \\
(0.013)\end{array}$ \\
\hline Observations & 216 \\
\hline
\end{tabular}

Based on data from the second wave of the survey. Intention to return to native country is measured by a dummy variable that takes the value one if the respondent is planning to go back to the country of origin for good and zero otherwise. Standard errors are in parentheses

${ }^{\text {a }}$ Significant at $10 \%$

${ }^{\mathrm{b}}$ Significant at $5 \%$ 
low-educated Muslims, who witnessed a significant relative increase in geographic concentration and unemployment. ${ }^{20}$

\subsection{Integration attitudes and return plans}

To show the relevance of attitudes in assessing immigrant integration, we estimate the relationship between perceived integration and the intention to permanently return to the native country. Respondents in the second wave of the survey were asked, "Do you plan to go back to your country of origin for good?". Twenty-three percent of all respondents (18\% of Muslims and 26\% of non-Muslims) reported a willingness to re-migrate permanently. We estimate a probit model in which the outcome variable is the intention to permanently remigrate to the country of origin, and the main regressors are the change in perceived integration across the two waves of the study and the pre-attacks level of integration, in addition to relevant control variables. ${ }^{21}$ Table 5 reports the marginal effects and shows that decline in perceived integration (and preattacks level of perceived integration) are significantly associated with higher intention to permanently re-migrate to the country of origin. However, unemployment and geographic concentration are not significantly related to the intention to re-migrate to the country of origin. This result suggests that this subjective measure of integration could be a strong better predictor of return migration. $^{22}$

\section{Conclusion}

We use panel data from the Netherlands that oversample the four largest ethnic minorities in the country (Turks, Moroccans, Surinamese, and Dutch Antilleans) to analyze the integration patterns of Muslim and non-Muslim immigrants before and shortly after a violent wave of Islamist terrorist attacks hit Western Europe. This wave of attacks began with the Madrid bombings in March 2004 and extended to the London bombings in July 2005. The assassination of Theo van Gogh in Amsterdam by an Islamic fanatic of Moroccan origin took place in the middle of this wave, triggering nationwide outrage and increasing discrimination against Muslims in the Netherlands (Gautier et al. 2009).

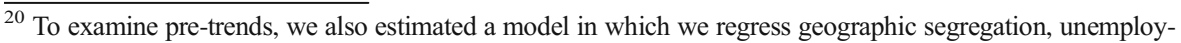
ment, and working hours separately on the time of the interview during the first wave interacted with a Muslim dummy. We find no significant pre-trends in Muslim immigrants' outcomes relative to non-Muslims.

${ }^{21}$ About $32 \%$ of the respondents (36\% of Muslims and $30 \%$ of non-Muslims) witnessed a decline in their perceived integration across the two waves.

22 The control variables shown are from the second wave. However, estimation results do not change when we control for the pre-attack levels of the control variables or the changes in the variables between the two waves. To capture any differences in the relationship between the change in perceived integration and the intention to permanently return to the native country between Muslim and non-Muslim immigrants, we have re-estimated the model controlling for the interaction between being a Muslim and the change in perceived integration. The coefficient of the interaction term shows no significant differences between the two groups, suggesting that the two groups of migrants do not respond differently to a decline in integration.
} 
We show that Muslim immigrants' attitudes toward integration became far more negative after the terrorist attacks than did those of non-Muslim immigrants. This pattern holds after including a large set of control variables and accounting for selection bias and is not driven by any negative trend in the integration of Muslim immigrants prior to the attacks. While the integration attitudes of high-educated Muslims were affected the most negatively by the terrorist attacks, low-educated Muslim immigrants were affected more negatively in terms of geographic concentration and unemployment.

The difference in the impact of terrorist attacks on geographic concentration between low-educated and high-educated Muslims could be due to the fact that low-educated immigrants are less often employed (or became more unemployed due to the attacks) than those who are highly educated and, therefore, (became) less constrained to move geographically. Moreover, the decline in house prices in areas with high concentrations of Muslim immigrants could be another driving force for low-educated Muslims to move to these areas. This increase in the geographic concentration of low-educated Muslims after the attacks could be a buffer that mitigates the effect of terrorism on their perceived integration, since they could obtain social support from being in a community of the same ethnic background. This could explain why low-educated migrants do not perceive discrimination as much as the highly educated do.

Despite the difficulty to claim causality, the paper provides strong suggestive evidence, using a panel data structure, that terrorism committed by Muslim fundamentalists, and its negative sociopolitical aftermath, could negatively affect the attitudes of moderate and high-educated Muslims toward integration in Western societies. We further find that integration attitudes are negatively associated with migrants' intention to return to their native country. This result emphasizes the relevance of integration attitudes. Given that migrants who arguably have strong potential for integration (i.e., the highly educated, employed, and less religious) witnessed the greatest decline in integration attitudes, they are the most likely to permanently re-migrate to their country of origin. This suggests that policy makers should acknowledge that the outrage against Muslims in the aftermath of the Islamist terrorist attacks has a negative impact on the prospective stay of the most productive Muslim immigrants in the host country, which could have negative economic implications for the knowledge economy of Western societies.

Acknowledgements We acknowledge the comments on earlier versions of our paper by two anonymous referees, Marion Collewet, Denis de Crombrugghe, Jan Feld, Stephen Machin, Alan Manning, Maria Paula Gerardino, Olivier Marie, Jeffrey Nugent, Jörn-Steffen Pischke, Nicolas Salamanca, and Maria Zumbuehl, as well as participants of the Economic Research Forum (ERF) 2013 conference in Kuwait, the 2013 "Migration: Global Development, New Frontiers" conference at UCL, the 16th IZA European Summer School in Labor Economics in Buch/Ammersee, Germany, the EALE, Conference in Ljubljana, Slovenia, and the CEP/LSE Labour Seminar in London School of Economics. The Netherlands Kinship Panel Study is funded by grant 480-10-009 from the Major Investments Fund of the Netherlands Organization for Scientific Research (NWO) and by the Netherlands Interdisciplinary Demographic Institute (NIDI), Utrecht University, the University of Amsterdam and Tilburg University.

\section{Compliance with ethical standards}

Conflict of interest The authors declare that they have no conflict of interest. 


\section{Appendix}

Table 6 Descriptive statistics

\begin{tabular}{|c|c|c|c|}
\hline Variable & Non-Muslim & Muslim & $P$ value \\
\hline \multicolumn{4}{|l|}{ Integration items } \\
\hline Excellent opportunities for foreigners & 3.11 & 3.25 & 0.272 \\
\hline No hostility against foreigners & 3.49 & 3.30 & 0.043 \\
\hline Rights of foreigners are respected & 3.39 & 3.13 & 0.013 \\
\hline Netherlands is hospitable to foreigners & 3.54 & 3.09 & 0.000 \\
\hline People in the Netherlands are not indifferent to migrants & 3.02 & 2.94 & 0.389 \\
\hline In the Netherlands foreigners are treated fairly & 3.33 & 3.14 & 0.066 \\
\hline In the Netherlands foreigners are not restricted & 3.27 & 2.66 & 0.000 \\
\hline The Netherlands is open to foreign cultures & 3.65 & 3.53 & 0.237 \\
\hline Feeling at ease with Dutch natives & 3.90 & 3.79 & 0.000 \\
\hline Appreciation of living in the Netherlands & 3.57 & 3.18 & 0.165 \\
\hline Perceived integration index & 0.00 & -0.26 & 0.000 \\
\hline \multicolumn{4}{|l|}{ Demographic variables } \\
\hline Female & 0.56 & 0.41 & 0.002 \\
\hline Age & 44.05 & 41.63 & 0.041 \\
\hline Highly educated (Intermediate secondary or higher) & 0.45 & 0.24 & 0.000 \\
\hline Length of stay in the Netherlands & 21.41 & 21.44 & 0.973 \\
\hline \multicolumn{4}{|l|}{ Employment status } \\
\hline Employed & 0.65 & 0.53 & 0.012 \\
\hline Unemployed & 0.06 & 0.08 & 0.471 \\
\hline Housewife & 0.10 & 0.18 & 0.009 \\
\hline Disabled & 0.09 & 0.12 & 0.403 \\
\hline Student & 0.04 & 0.02 & 0.354 \\
\hline Retired & 0.06 & 0.07 & 0.749 \\
\hline Working hours & 37.10 & 37.74 & 0.558 \\
\hline \multicolumn{4}{|l|}{ Ethnic minority } \\
\hline Turkish & 0.00 & 0.58 & 0.000 \\
\hline Moroccan & 0.00 & 0.26 & 0.000 \\
\hline Surinamese & 0.40 & 0.12 & 0.000 \\
\hline Dutch Antilleans & 0.60 & 0.04 & 0.000 \\
\hline $\begin{array}{l}\text { Share of ethnic group in municipality } \\
\text { (geographic concentration) in percentage points }\end{array}$ & 3.65 & 5.08 & 0.000 \\
\hline \multicolumn{4}{|l|}{ Marital status } \\
\hline Never married & 0.04 & 0.04 & 0.000 \\
\hline Married & 0.42 & 0.80 & 0.000 \\
\hline Divorced & 0.25 & 0.14 & 0.001 \\
\hline Widowed & 0.28 & 0.03 & 0.306 \\
\hline \multirow[t]{2}{*}{ Number of children } & 2.20 & 2.62 & 0.018 \\
\hline & 280 & 152 & \\
\hline
\end{tabular}


Table 7 Difference-in-difference estimates of integration attitudes before and after the terrorist attacks

\begin{tabular}{|c|c|c|c|c|c|}
\hline \multirow[t]{3}{*}{ Variables } & \multicolumn{2}{|c|}{ Non-Muslims } & \multicolumn{2}{|l|}{ Muslims } & \multirow[t]{3}{*}{ Diff. in diff. } \\
\hline & Before & After & Before & After & \\
\hline & $N=76$ & $N=76$ & $N=140$ & $N=140$ & \\
\hline \multirow[t]{2}{*}{ (1) Excellent opportunities for foreigners } & 3.26 & 2.96 & 3.79 & 2.71 & \multirow[t]{2}{*}{$-0.78^{\mathrm{c}}$} \\
\hline & $(1.14)$ & $(1.21)$ & $(1.14)$ & $(1.23)$ & \\
\hline \multirow[t]{2}{*}{ (2) No hostility against foreigners } & 3.64 & 3.34 & 3.47 & 3.12 & \multirow[t]{2}{*}{-0.06} \\
\hline & $(0.84)$ & $(1.02)$ & $(0.97)$ & $(0.89)$ & \\
\hline \multirow[t]{2}{*}{ (3) Rights of foreigners are respected } & 3.47 & 3.30 & 3.41 & 2.86 & \multirow[t]{2}{*}{$-0.38^{\mathrm{a}}$} \\
\hline & $(0.88)$ & $(1.01)$ & $(1.01)$ & $(1.15)$ & \\
\hline \multirow[t]{2}{*}{ (4) NL is hospitable to foreigners } & 3.77 & 3.31 & 3.34 & 2.83 & \multirow[t]{2}{*}{-0.06} \\
\hline & $(0.93)$ & $(1.13)$ & $(1.01)$ & $(1.17)$ & \\
\hline \multirow[t]{2}{*}{ (5) People in NL are not indifferent to migrants } & 3.01 & 3.04 & 2.96 & 2.92 & \multirow[t]{2}{*}{-0.06} \\
\hline & $(1.00)$ & $(0.89)$ & $(1.020$ & $(0.99)$ & \\
\hline \multirow[t]{2}{*}{ (6) In NL foreigners are treated fairly } & 3.43 & 3.22 & 3.54 & 2.75 & \multirow[t]{2}{*}{$-0.58^{\mathrm{c}}$} \\
\hline & $(0.92)$ & $(0.95)$ & $(0.880$ & $(1.02)$ & \\
\hline \multirow[t]{2}{*}{ (7) In NL foreigners are not restricted } & 3.39 & 3.16 & 2.74 & 2.58 & \multirow[t]{2}{*}{0.07} \\
\hline & $(1.00)$ & $(1.03)$ & $(1.080$ & $(1.09)$ & \\
\hline \multirow[t]{2}{*}{ (8) NL is open to foreign cultures } & 3.69 & 3.61 & 3.82 & 3.25 & \multirow[t]{2}{*}{$-0.49^{\mathrm{b}}$} \\
\hline & $(0.89)$ & $(0.98)$ & $(0.90)$ & $(1.12$ & \\
\hline \multirow[t]{2}{*}{ (9) Feeling at ease with Dutch natives } & 3.67 & 3.47 & 3.36 & 3.01 & \multirow[t]{2}{*}{-0.14} \\
\hline & $(0.48)$ & $(0.69)$ & $(0.69)$ & $(0.76)$ & \\
\hline \multirow[t]{2}{*}{ (10) Appreciation of living in the Netherlands } & 3.99 & 3.82 & 3.99 & 3.59 & \multirow[t]{2}{*}{-0.23} \\
\hline & $(0.74)$ & $(0.74)$ & $(0.84)$ & $(0.98)$ & \\
\hline \multirow[t]{2}{*}{ (11) Perceived integration } & 0.11 & -0.11 & -0.004 & -0.51 & \multirow[t]{2}{*}{$-0.29^{\mathrm{b}}$} \\
\hline & $(0.57)$ & $(0.64)$ & $(0.51)$ & $(0.70)$ & \\
\hline
\end{tabular}

Diff. in diff. $=\left(\right.$ Muslim $_{\mathrm{after}}-$ Muslim $\left._{\mathrm{before}}\right)-($ non-Muslim $\mathrm{after}-$ non-Muslim $\mathrm{before})$ NL $=$ the Netherlands. Standard deviations are in parentheses

${ }^{\text {a }}$ Significant at $10 \%$

${ }^{\mathrm{b}}$ Significant at $5 \%$

${ }^{\mathrm{c}}$ Significant at $1 \%$ 
Table 8 Change in the integration of Muslim and non-Muslim immigrants after the terrorist attacks, FE model

Variables

Perceived integration

(1)

\section{Muslim}

Post-attacks

$-0.502^{\mathrm{a}}$

(0.297)

Muslim $\times$ Post-attacks

$-0.284^{\mathrm{b}}$

(0.118)

Constant

$-1.455$

(1.361)

Yes

No

432

216
$-0.118$

(0.383)

$-0.299^{\mathrm{b}}$

$-0.550$

No

Yes

432

216

Perceived integration is measured by an index of the equally weighted averages of the $z$-scores (based on the mean and standard deviation of the non-Muslim group) of the 10 integration items. The variable Muslim is a dummy variable for being Muslim and Post-attacks takes the value one if the observation is from the second wave (after the terrorist attacks) and zero otherwise. Column 1 controls for the interaction between being a Muslim and all the controls. Column 3 controls for the interaction between Post-attacks and all the controls. The interacted control variables are gender, employment status, education, marital status, ethnic group, number of children, length of stay in the Netherlands (squared), and regional dummies. Robust standard errors are in parentheses

a Significant at $10 \%$

${ }^{\mathrm{b}}$ Significant at $5 \%$ 
Table 9 Change in the integration attitudes of Muslim and non-Muslim immigrants after terrorist attacks, separate estimations for each item in the integration index

Variables

FE

(1) Excellent opportunities for foreigners

Muslim $\times$ Post-attacks

(2) No hostility against foreigners

Muslim $\times$ Post-attacks

(3) Rights of foreigners are respected

Muslim $\times$ Post-attacks

(4) NL is hospitable to foreigners

Muslim $\times$ Post-attacks

(5) People in NL are not indifferent to migrants

Muslim $\times$ Post-attacks

(6) In NL foreigners are treated fairly

Muslim $\times$ Post-attacks

(7) In NL foreigners are not restricted

Muslim $\times$ Post-attacks

(8) NL is open to foreign cultures

Muslim $\times$ Post-attacks

(9) Feeling at ease with Dutch natives

Muslim $\times$ Post-attacks

(10) Appreciation of living in the Netherlands

Muslim $\times$ Post-attacks

Controls

Yes

Observations

432

Number of individuals

216

The controls are as in Table 1. The variable Muslim is a dummy variable for being Muslim and Post-attacks takes the value one if the observation is from the second wave (after the terrorist attacks) and zero otherwise. Robust standard errors are in parentheses

${ }^{\mathrm{b}}$ Significant at $5 \%$

${ }^{\mathrm{c}}$ Significant at $1 \%$ 
Table 10 Change in the integration of Muslim and non-Muslim immigrants after the terrorist attacks excluding extremely high pre-attacks levels of integration

\begin{tabular}{lll}
\hline Variables & Perceived integration & $(2)$ \\
\hline Muslim & $(1)$ & - \\
Post-attacks & - & -0.412 \\
& $-0.193^{\mathrm{c}}$ & $(0.297)$ \\
Muslim $\times$ Post-attacks & $(0.058)$ & $-0.268^{\mathrm{b}}$ \\
& $-0.235^{\mathrm{b}}$ & $(0.108)$ \\
Constant & $(0.101)$ & -0.805 \\
& -0.034 & $(1.294)$ \\
Observations & $(0.024)$ & 384 \\
$R^{2}$ & 384 & 0.280 \\
Number of individuals & 0.172 & 192 \\
\hline
\end{tabular}

The controls are as in Table 1 . The highest $10 \%$ in terms of the pre-attack level of the integration index is excluded. Perceived integration is measured by an index of the equally weighted averages of the z-scores (based on the mean and standard deviation of the non-Muslim group) of the 10 integration items. The variable Muslim is a dummy variable for being Muslim and Post-attacks takes the value one if the observation is from the second wave (after the terrorist attacks) and zero otherwise. Robust standard errors are in parentheses

a Significant at $10 \%$

${ }^{\mathrm{b}}$ Significant at $5 \%$

${ }^{\mathrm{c}}$ Significant at $1 \%$

Table 11 Trends in integration before and after the attacks, OLS estimates

\begin{tabular}{lll}
\hline Variables & Perceived integration & $(2)$ \\
& $(1)$ & After \\
\hline Muslim & Before & -0.093 \\
& -0.444 & $(0.320)$ \\
Time of interview (in quarters) & $(0.271)$ & $0.187^{\mathrm{c}}$ \\
& -0.040 & $(0.060)$ \\
Muslim $\times$ Time of interview & $(0.050)$ & -0.109 \\
& 0.114 & $(0.104)$ \\
Constant & $(0.085)$ & $-1.331^{\mathrm{c}}$ \\
Controls & -0.051 & $(0.338)$ \\
Observations & $(0.209)$ & Yes \\
$R^{2}$ & Yes & 212 \\
\hline
\end{tabular}

The time of the interview is measured in quarters. The number of observations is slightly smaller, since we have no information on the timing for 18 interviews. The controls include gender, employment status, education, marital status, number of children, length of stay in the Netherlands (squared), and regional dummies. Robust standard errors are in parentheses

${ }^{\mathrm{c}}$ Significant at $1 \%$ 


\section{References}

Abadie A, Gardeazabal J (2008) Terrorism and the world economy. Eur Econ Rev 52(1):1-27

Adida CL, Laitin DD, Valfort MA (2014) Muslims in France: identifying a discriminatory equilibrium. J Popul Econ 27(4):1039-1086

Arai M, Karlsson J, Lundholm M (2011) On fragile grounds: a replication of "are Muslim immigrants different in terms of cultural integration?". J Eur Econ Assoc 9(5):1002-1011

Åslund O, Rooth D (2005) Shifts in attitudes and labor market discrimination: Swedish experiences after 9-11. J Popul Econ 18(4):603-629

Bakker E (2006) Jihadi terrorists in Europe. Netherlands Institute for International Relations Clingendael, Den Haag

Banerjee R (2008) An examination of factors affecting perception of workplace discrimination. J LABOR RES 29(4):380-401

Battu H, Zenou Y (2010) Oppositional identities and employment for ethnic minorities: evidence from England. Econ J 120(542):F52-F71

Becker G (1957) The economics of discrimination. University of Chicago Press, Chicago

Bisin A, Patacchini E, Verdier T, Zenou Y (2008) Are Muslim immigrants different in terms of cultural integration? J Eur Econ Assoc 6:445-456

Braakmann N (2010) Islamistic terror and the labour market prospects of Arab men in England: does a country's direct involvement matter? SCOT J POLIT ECON 57(4):430-454

Casey T, Dustmann C (2010) Immigrants' identity, economic outcomes and the transmission of identity across generations. Econ J 120(542):F31-F51

Clingingsmith D, Khwaja AI, Kremer M (2009) Estimating the impact of the hajj: religion and tolerance in Islam's global gathering. Q J Econ 124(3):1133-1170

Cornelissen T, Jirjahn U (2012) September 11th and the earnings of Muslims in Germany: the moderating role of education and firm size. J Econ Behav Organ 81(2):490-504

Dávila A, Mora TM (2005) Changes in the earnings of Arab men in the US between 2000 and 2002. J Popul Econ 18(4):587-601

Dykstra PA, Kalmijn M, Knijn TC, Komter AE, Liefbroer AC, Mulder CH (2005) Codebook of the Netherlands kinship panel study, a multi-actor, multi-method panel study on solidarity in family relationships, wave 1. NKPS Working Paper 4. Netherlands Interdisciplinary Demographic Institute, The Hague

Dykstra PA, Kalmijn M, Knijn TC, Komter AE, Liefbroer AC, Mulder CH (2012) Codebook of the Netherlands kinship panel study, a multi-actor, multi-method panel study on solidarity in family relationships, wave 2. NKPS Working Paper 8. Netherlands Interdisciplinary Demographic Institute, The Hague

Gautier P, Siegmann A, Van Vuuren A (2009) Terrorism and attitudes towards minorities: the effect of the Theo van Gogh murder on house prices in Amsterdam. J Urban Econ 65(2):113-126

Georgiadis A, Manning A (2011) Change and continuity among minority communities in Britain. J Popul Econ 24(2):541-568

Georgiadis A, Manning A (2013) One nation under a groove? Understanding national identity. J Econ Behav Organ 93:166-185

Gijsberts M (2005) Opvattingen van autochtonen en allochtonen over de multi-etnische samenleving. In: SCP/ WODC/CBS (ed) Jaarrapport Integratie 189-205. SCP/WODC/CBS, The Hague

Global Terrorism Database (2012) National consortium for the study of terrorism and responses to terrorism (START). Retrieved from http://www.start.umd.edu/gtd

Goel D (2010) Perceptions of immigrants in Australia after 9/11. Econ Rec 86(275):596-608

Gould ED, Klor EF (2010) Does terrorism work? Q J Econ 4:1459-1510

Gould ED, Klor EF (2015) The long-run effect of 9/11: terrorism, backlash, and the assimilation of Muslim immigrants in the west. Econ J. doi:10.1111/ecoj.12219

Hanes E, Machin S (2014) Hate crime in the wake of terror attacks: evidence from 7/7 and 9/11. Journal of Contemporary Criminal Justice 30(3):247-267

Huijnk W, Verkuyten M, Coenders M (2012) Family life and acculturation attitudes: a study among four immigrant groups in the Netherlands. J Ethn Migr Stud 38(4):555-575

Johnston DW, Lordan G (2012) Discrimination makes me sick! An examination of the discrimination-health relationship. J Health Econ 31(1):99-111

Kaushal N, Kaestner R, Reimers C (2007) Labor market effects of September 11th on Arab and Muslim residents of the United States. J Hum Resour 42(2):275-308

Kling JR, Liebman JB (2004) Experimental analysis of neighborhood effects on youth. Princeton IRS Working Paper 483, March 
Kling JR, Liebman JB, Katz LF (2007) Experimental analysis of neighborhood effects. Econometrica 75(1): 83-119

Kydd AH, Walter BF (2006) The strategies of terrorism. INT SECURITY 31(1):49-80

Manning A, Roy S (2010) Culture clash or culture club? National identity in Britain. Econ J 120(542):F72F100

Miaari S, Zussman A, Zussman N (2012) Ethnic conflict and job separations. J Popul Econ 25(2):419-437

Michaels G, Zhi X (2010) Freedom fries. AM ECON J-APPL ECON 2(3):256-281

Mitrut A, Wolff FC (2014) Investing in children's education: are Muslim immigrants different? J Popul Econ 27(4):999-1022

Moser P (2012) Taste-based discrimination evidence from a shift in ethnic preferences after WWI. Explor Econ Hist 49(2):167-188

Nesser P (2008) Chronology of jihadism in Western Europe 1994-2007: planned, prepared, and executed terrorist attacks. STUD CONFL TERROR 3:924-946

Rabby F, Rodgers III WM (2010) The impact of 9/11 and the London bombings on the employment and earnings of UK Muslims. IZA Discussion Papers 4763

Rabby F, Rodgers WM III (2011) Post 9-11 US Muslim labor market outcomes. Atl Econ J 39(3):273-289

Schüller S (2016) The effects of 9/11 on attitudes toward immigration and the moderating role of education. Kyklos 69(4):604-632

Shannon M (2012) Did the September 11th attacks affect the Canadian labour market? Econ Lett 115(1):9193

Shayo M, Zussman A (2011) Judicial ingroup bias in the shadow of terrorism. Q J Econ 26(3):1447-1484

Steedman H, McIntosh S (2001) Measuring low skills in Europe: how useful is the ISCED framework? OXFORD ECON PAP 53(3):564-581 